\title{
Quercus ×numidica Trabut (Fagaceae, Quercoideae) and Cynosuro peltierii- Quercetum afaredis Laribi ex El Mokni ass. nov. new taxon and syntaxon to Kroumirian oak forests of Tunisia with remarks on their ecology and conservation
}

\author{
Ridha El Mokni ${ }^{1,2,3}$ (D)
}

Key words: chorology, conservation, endemism, Kroumiria, Quercus afares, Rosids.

Ključne besede: horologija, ohranjanje, endemizem, Kroumiria, Quercus afares, Rosids.

\begin{abstract}
The very little-known Quercus xnumidica Trabut, recently typified and synonymised to Q. ×kabylica Trabut, was found within the Cynosuro peltieriiQuercetum afaredis Laribi ex El Mokni ass. nov. (Quercion suberis Loisel 1971). Both the taxon and the syntaxon are described here for the first time for the oak forests of Kroumiria in Tunisia. The distribution, ecology and field photographs of the new taxon are presented and IUCN Red List assessment is provided in this paper. Threats at the national level are assessed and conservation measures for the taxon are proposed.

Izvleček

Manj znani takson Quercus $\times$ numidica Trabut, ki so ga pred kratkim tipizirali in hkrati opredelili takson Q. xkabylica Trabut kot njegov sinonim, smo našli v sestojih asociacije Cynosuro peltierii-Quercetum afaredis Laribi ex El Mokni ass. nov. (Quercion suberis Loisel 1971). Pojavljanje taksona in sintaksona smo prvič opisali v hrastovih gozdovih na območju Kroumiria v Tuniziji. Predstavili smo razširjenost, ekologijo in terenske fotografije novega taksona in podali oceno po IUCN rdečem seznamu. Ocenili smo grožnje na nacionalni ravni in predlagali ukrepe za ohranjanje.
\end{abstract}

Corresponding author:

Ridha El Mokni

E-mail: ridhaelmokni@yahoo.fr

Received: 16. 8. 2021

Accepted: 8. 10. 2021

\footnotetext{
1 Department of Pharmaceutical Sciences "A”, Laboratory of Botany, Cryptogamy and Plant Biology, Faculty of Pharmacy of Monastir, Monastir, Tunisia.

2 University of Carthage, Laboratory of Forest Ecology, National Research Institute of Rural Engineering, Water and Forests, Ariana, Tunisia.

3 University of Jendouba, Department of Silvo-Pastoral Resources, Laboratory of Silvo-Pastoral Resources, Silvo-Pastoral Institute of Tabarka, Tabarka, Tunisia.
} 


\section{Introduction}

Quercus $\times$ numidica was first described by Trabut (1889) as one of several taxa found in Algerian oak forests, referring to 'faux lièges or pseudo-lièges' (false cork oaks / Quercus pseudosuber var. castaneaefolia Wenzig) that he mentioned "Quercus numidica Trabut sp. nov." with the parentage $Q$. afares Pomel $\times Q$. suber L. Traditionally, this hybrid was thought to be a different taxon than a very close hybrid that referred to Quercus $\times k a b-$ ylica Trabut (Trabut, 1890). More recently, Coombes \& Vázquez (2021) have confirmed that both taxa represent variants resulting from hybridization between $Q$. afares and $Q$. suber and are synonyms, the earliest and correct name being $Q$. xnumidica Trabut.

This taxon has been attributed to a very restricted distribution, limited to the Algerian oak forests mainly of Bouzegza, Yakouren, Akfadou and Guerrouch [A1, K1 and K2 subsector sensu Quézel \& Santa (1962)] (Coombes \& Vázquez, 2021). Therefore, we here report the first locality of this taxon in the oak forests of Kroumiria in Tunisia.

\section{Material and methods}

In 2018, during botanical field surveys in the mountains of the Kroumiria region (in northwestern Tunisia) and its surroundings, we discovered for the first time some individuals of "an afares oak like with atypical leaf shape". Some vouchers were taken for further studies and a phytosociological relevé was made (see Table 1 ).

Two years later (2020), more specimens were discovered at the same site and more vouchers were collected. In addition, phytosociological relevé was done in an area where the largest population of Quercus afares grows in Tunisia. Many vouchers are housed in the personal collection of the authors (R. El Mokni), deposited in the Herbarium of the University of Monastir (not listed in Index Herbariorum) and at PO (codes after Thiers (2021)). The collected specimens were compared with those deposited in the MPU [mainly Lectotype of Quercus ×numidica, (MPU barcode MPU-161864) and Lectotype of Quercus ×kabylica (MPU barcode MPU-010440), MPU-007895, MPU-010435, MPU-010436, MPU-010437, MPU010438, MPU-010439, MPU-010441, MPU-161863, MPU-271761, MPU-271763, MPU-271764 and MPU271769] and P [P-05558810, P-06847710, P-06847796, P-06860940, P-06861705, P-06861708, P-06861709 and P-06861730]. The phytosociological relevés were collected following the approach of Braun-Blanquet (1964). The nomenclature of syntaxonomic units follows Laribi
(2000), Laribi et al. (2008), Meddour et al. (2010), Meddour et al. (2017) and Mucina et al. (2016), while the nomenclature of plants is in agreement with Dobignard \& Chatelain (2010-2013) and APD (2021). In addition, the relevant literature was analysed and the digital images of the specimens kept in the MPU and P herbaria were examined.

\section{Results and discussion}

During field surveys in the oak forests of Kroumiria in Tunisia, specimens corresponding to the morphological characteristics of an hybrid of Quercus suber and Q. afares, Q. $\times$ numidica, were observed and collected.

The comparison of the collected specimens with those deposited in the MPU confirms that the features (especially in the leaves) of the new oak match Quercus $\times n u$ midica Trabut (syn. Q. xkabylica Trabut) and that no such evidence exists for Tunisia so far.

\section{Selected examined specimens}

ALGERIA (historical records): Guerrouch, Juillet 88 (MPU-161864). Akfadou, without date, Trabut (MPU007895). Forêt de l'Akfadou, without date, l. Trabut s.n. (MPU-010435). Akfadou, October 1888, l. Trabut s.n. (MPU-010435, MPU-010436, MPU-010437, MPU010438, MPU-010439, MPU-010440, MPU-010441, P-06861705, P-06861708). Forêt de Guerrouch, 1891, Trabut (MPU-161863). Chênaies des pentes supérieures du Dj. Goufi, vers 1000 mètres. En revenant Tamesguida, 13 Avril 1955, herbier H. Gillet (P-05558810, PL-05222613). Kabylie de Collo. 24 mai 1944, herbier L. Faurel (P-06847710, PL-05206190, MPU-284133). Chênaies des pentes supérieures du Djebel Goufi, vers 1000 mètres. Kabylie de Collo. 17 mai 1944, herbier L. Faurel (P-06847796, PL-05206678, MPU-284134). Kabylie, without locality, June 1887 , l. Trabut s.n. (P-06861709). Taourirt Irhil, June 1889, l. Trabut s.n. (P-06861730). Yakouren, without date, l. Trabut s.n. (MPU-271761). In quercetis montis Bouzegza, solo arenaceo, 700-800 m a.s.1., 22-05-1932, R. Maire s.n. (P-06860940, MPU-271763). Forêt de Guerrouch, 1891, l. Trabut s.n. (MPU-271764). Massif de l'Akfadou près Yakouren, without date, Charlemagne s.n. (MPU271769). TUNISIA (new records): Jendouba; Aîn Draham, Aîn Zana, mixed oak forest on sandstone-clayey soil, approximately $950 \mathrm{~m}$ a.s.1., $036^{\circ} 44^{\prime} 12^{\prime \prime} \mathrm{N}, 008^{\circ} 51^{\prime} 34^{\prime \prime} \mathrm{E}$, R. El Mokni, 20 March 2018 El Mokni s.n. (PO, Herb. El Mokni), ibidem 16 June 2020, El Mokni s.n. (Herb. El Mokni). 


\section{Morphology (Figure 2)}

Tree as tall as that of Q. afares, reaching more than $20 \mathrm{~m}$ in height in the wild; trunk almost single, straight, with diameter nearly always constant; bark somewhat corky; young shoots tomentose; leaves ovate to elliptic, tapered to rounded at the base and tomentose on the under surface, very variable in shape and size, some resembling those of $Q$. suber, others resembling those of $Q$. afares but smaller, sharply toothed to almost entire, late deciduous, overwintering; petiole very short to $2 \mathrm{~cm}$ long; cups to $2 \mathrm{~cm}$ across with recurved scales; acorns ovoid, about $3 \mathrm{~cm}$ long, half enclosed in the cup and ripening in the second year (see more in Trabut (1890) and Coombes \& Cameron (2021)).

\section{Distribution of this rare endemic taxon in North Africa}

Although Quercus × numidica appears to have a fairly continuous distribution range (in the oak forests of Algeria and Tunisia), its occurrence, although extending from Algiers to Skikda, is scattered (forests of Bouzegza, Yakouren, Akfadou and Guerrouch) and rare, as recently mentioned by Coombes \& Vázquez (2021). East of Collo (Skikda) in Algeria has not been reported, even in historical records. Its rarity is mainly due to confusion with Quercus afares individuals and may increase in the future due to habitat destruction, hydrological degradation, fires and ongoing global change. To date, Quercus $\times$ numidica has been reported from the seven main historical sites of natural populations in Algeria (Bouzegza, Yakouren,
Akfadou, Taourirt Ighil, Guerrouch, Tamesguida, djebel Goufi), with no known actual status. No other sites were published or confirmed after the year 1961.

A recent monitoring of the floristic diversity of the Kroumirian oak forests and their ecological features in northwestern of Tunisia revealed an additional population of Quercus ×numidica, as neither historical localities nor specimens preserved in the MPU and P herbaria were found.

The updated occurrence of Quercus $\times$ numidica in North Africa is shown here in Figure 1.

\section{Notes on the associated species in Tunisian locality}

Quercus $\times$ numidica was found together with many North African/Tunisian-Algerian endemics (see Table 1) within the Cynosuro peltierii-Quercetum afaredis Laribi 2000. This association was in fact invalidly described by Laribi (2000) since only a synthetic table has been presented.

Cynosuro peltierii-Quercetum afaredis Laribi 2000 nom. inval. (Art. 5 of the Code, 4th edition of the ICPN; Theurillat et al. (2020)). A single relevé is here selected as holotype and validating the name of this association as Cynosuro peltierii-Quercetum afaredis Laribi ex El Mokni ass. nov. (Holotypus: Table 1, relevé 2).

The syntaxonomic position of the association is as follow: Quercetea ilicis Br.-Bl. ex A. Bolós et O. de Bolós in A. Bolós y Vayreda 1950, Quercetalia ilicis Br.-Bl. ex Molinier 1934 and Quercion suberis Loisel 1971 (see Loisel, 1971; Meddour et al., 2010; Meddour et al., 2017; Mucina et al., 2016).

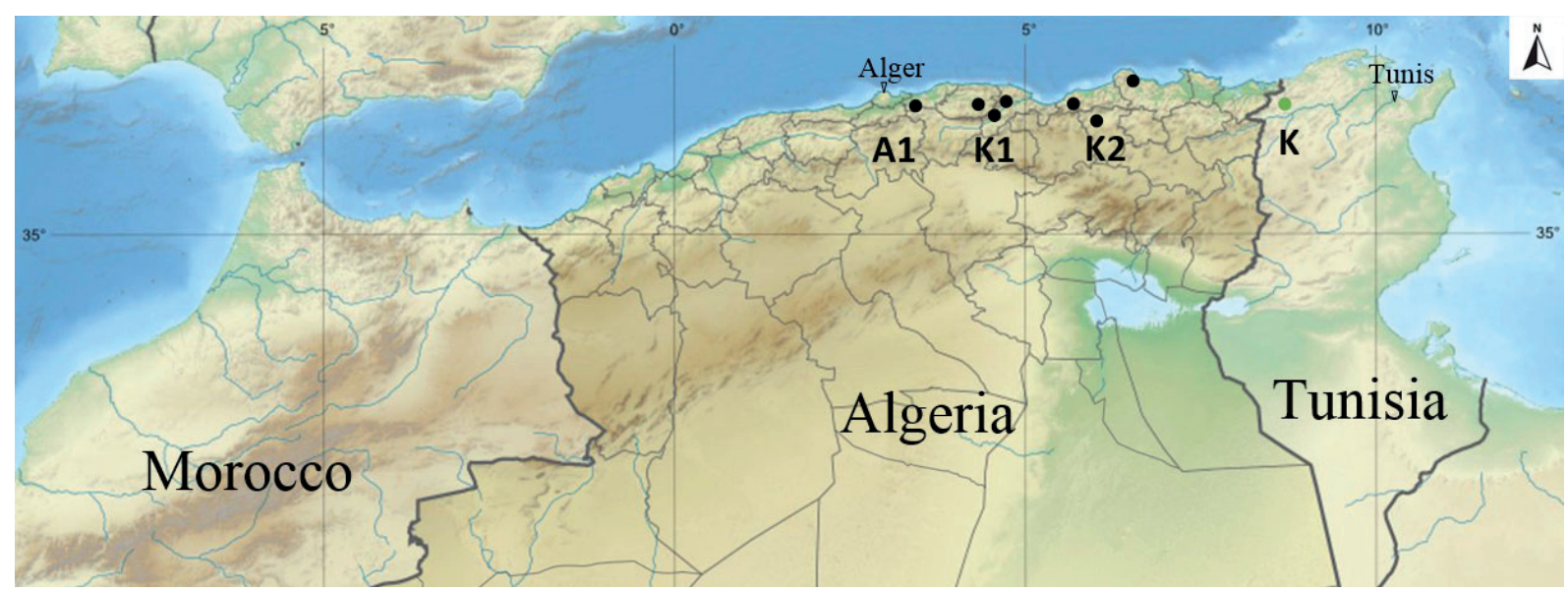

Figure 1: Distribution of Quercus $\times$ numidica in North Africa; the green point corresponds to the new record and the extreme eastern population (8. Jendouba/Aîn Draham/Aîn zana, NW Tunisia) and the black points to historical records, as follows from the west to the east: 1. Bouzegza, 2. Yakouren, 3. Akfadou, 4. Taourirt Ighil, 5. Guerrouch, 6. Tamesguida, 7. djebel Goufi (cf. Coombes \& Vázquez 2021; GBIF 2021). Slika 1: Razširjenost Quercus ×numidica v Severni Afriki; zelena točka predstavlja novo lokacijo in najbolj vzhodno populacijo (8. Jendouba /Aîn Draham/Aîn zana, SZ Tunizija), črna pa zgodovinske podatke od zahoda proti vzhodu: 1. Bouzegza, 2. Yakouren, 3. Akfadou, 4. Taourirt Ighil, 5. Guerrouch, 6. Tamesguida, 7. djebel Goufi (cf. Coombes \& Vázquez 2021; GBIF 2021). 


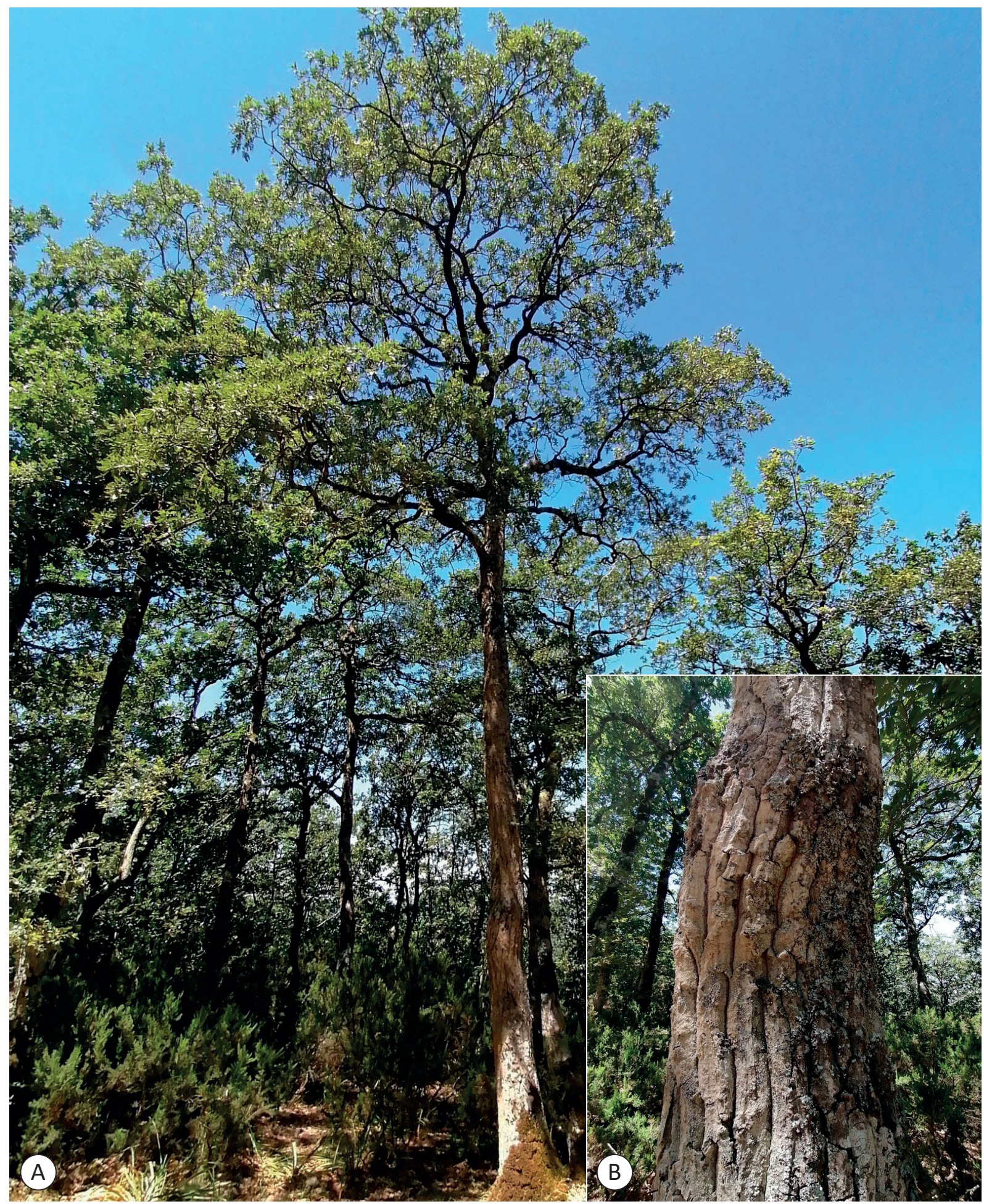

Figure 2: Quercus ×numidica (syn. Q. ×kabylica by Trabut 1890) in Kroumirian oak forests; A: habit of a tree in its natural habitat; B: part of the trunk with somewhat corky bark; C: crown; D: typical leaves; E: cups. (Jendouba, NW Tunisia, North Africa; 16.6.2020).

Photos by Ridha El Mokni.

Slika 2: Quercus ×numidica (syn. Q. ×kabylica Trabut 1890) v hrastovih gozdovih na območju Kroumiria; A: drevesa na naravnem rastišču; B: del debla z nekoliko oplutenelim lubjem; C: krošnja; D: značilni listi; E: plod. (Jendouba, SZ Tunizija, Severna Afrika; 16. 6. 2020).

Fotografije: Ridha El Mokni. 


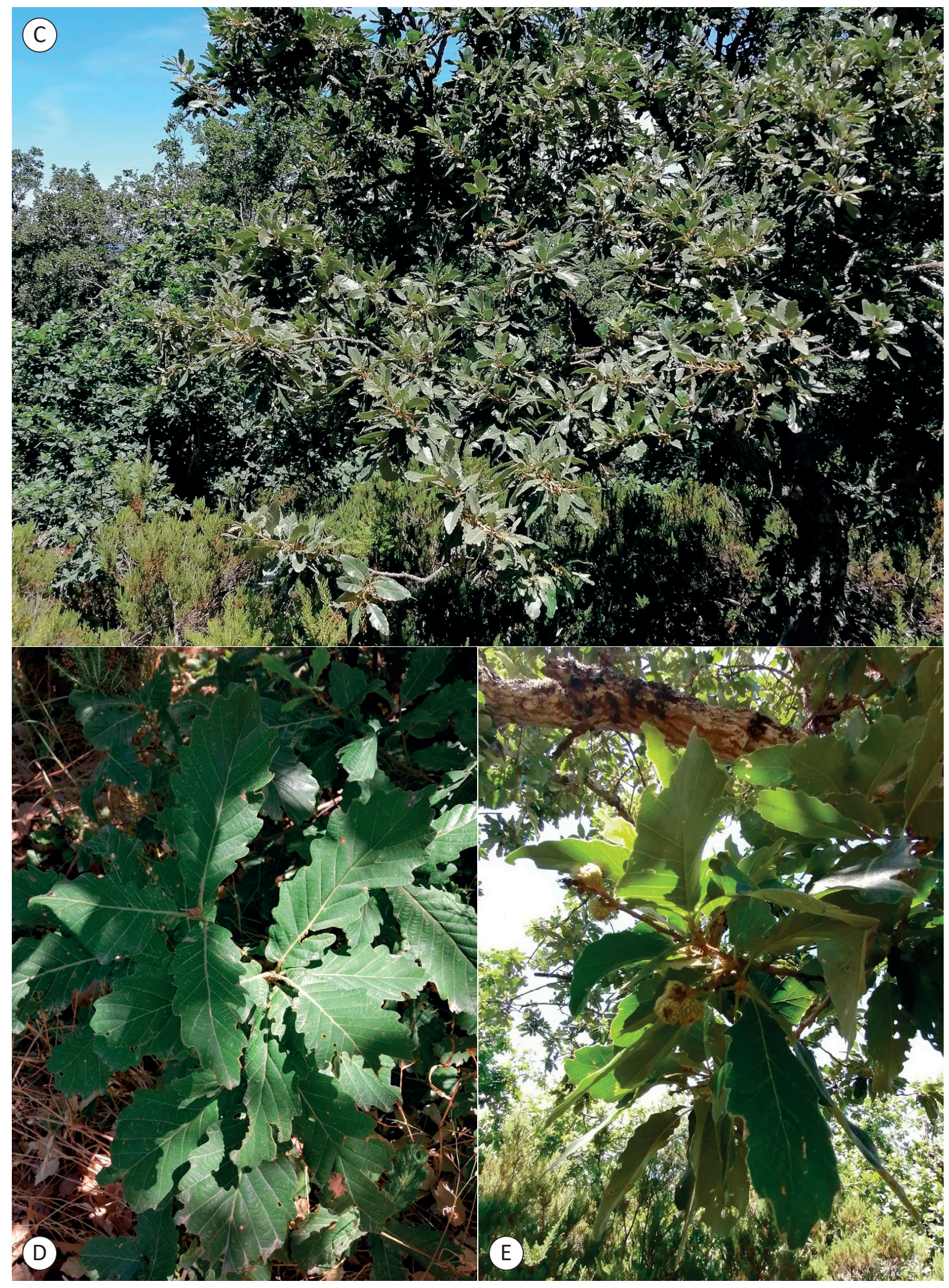


The association was defined in Algeria within the Great Kabylia biogeographic subsector [K1 sensu Quézel \& Santa (1962)], where the characteristic combination of this syntaxon includes Quercus afares Pomel, Cynosurus peltieri Maire (both endemic to northeastern Algeria and northwestern Tunisia), Galium tunetanum Poir. (an endemic of the Maghreb), Phlomis bovei de Noé subsp. bovei (a subspecies endemic to northeastern Algeria and northwestern Tunisia), and other taxa that are indicators of the temporary hydromorphic of clay soils (sub-numidian clays outcrop) occupied by the afares oak forest. These forests are determined, at least in part, by an edaphic determinism and are located almost between 1,000 and $1,300 \mathrm{~m}$ a.s.l. in a cool, humid bioclimate (as almost in Tunisia), in the upper Mesomediterranean, on the driest slopes facing west, southwest and south, mainly in the Akfadou forests (Laribi, 2000).

\section{Conservation status}

In total, we can name all included (historical and current records) eight populations/subpopulations of Quercus $\times$ numidica currently known in North Africa (Algeria and Tunisia). All populations are scattered with a limited number of individuals, not exceeding 20 for the Tunisian subpopulation. Their occurrence is still linked to oak forests dominated by afares oak.

Based on the IUCN Threats Classification Scheme (IUCN, 2021), we can highlight the following:

2. agriculture (2.3 Livestock farming, 2.3.1 Nomadic grazing): continuous overgrazing, whether in Tunisia with high numbers of goats or in Algeria with intensive frequentation by cattle (Meddour, 1993; Laribi, 2000), remains the most obvious threat to these communities and to the native biodiversity they host in these ecosystems. Persistent overgrazing leads to retrogression, encourages the growth and spread of weeds and plants of the pastoral rangelands (see Table 1), and leads to the depletion and even loss of native and endemic plant species;

3. energy production and mining (coal mining): the constant aggressive cutting of oak branches for heating coal can only reduce the performance of the trees, limiting their productivity and reducing their acorn production;

5. biological resource use (5.3 Logging and wood harvesting, 5.3.3 Unintentional effects: subsistence/small scale (species being assessed is not the target) [harvest]): illegal logging of oak trees has always continued and has become more frequent mainly in the last decade. Such behavior can only harm and deeply disturb any type of ecosystem balance and evolution;

7. changes in the natural system (7.1 Fire, 7.1.1 Increase in frequency/intensity of fires): the increase in the frequency of fires especially in the last decade (about 392 fires that burned more than 1300 ha of forest area within Aîn Draham delegation, Comm. Pers. L. Hamdi, forestry engineer in the Aîn Draham forestry delegation ) facilitates the fragmentation to irreversible habitat destruction and disrupts important processes such as gene flow; (7.3 Other ecosystem changes): the improper, excessive and continuous collection of litter under oaks by nurserymen can only destroy any soil process that favours the formation of a humus soil suitable sustaining this biodiversity;

12. other options (12.1 Other threats): the lack of effective habitat conservation strategies by governments, rehabilitation of burnt areas, and increasing the resilience of species populations to fire damage, compounded by the negative effects of very high visitation by non-target hikers and heavy trampling during the beatings of wild boars.

The eight reported populations at eight sites (historical and new records, Figure 1) have an AOO (Area Of Occupancy) of $40 \mathrm{~km}^{2}\left(<<500 \mathrm{~km}^{2}\right)$ and an EOO (Extend Of Occurrence) of $12,011 \mathrm{~km}^{2}$. Given a decline in the habitat quality (fragmentation, overgrazing and illegal continuous and excessive logging), Quercus xnumidica may be classified as Endangered [B2b(i,ii,iii,iv)c(i,ii,iii)] in North Africa, according to IUCN (2021) criteria.

\section{Conservation measures}

Despite the great efforts made for more than two decades in monitoring deciduous oaks (Quercus afares and Q. canariensis) and their high biodiversity, the work is still in its infancy and several conservation measures should be carried out urgently and more seriously. The conservation strategy for these endangered oaks (including the newly reported endangered deciduous oak Quercus ×numidica) requires at least: (i) in situ, putting an end to excessive and massive overgrazing, by including especially the areas where the newly discovered taxon (Quercus $\times$ numidica) is rampant, and declaring these oak forests prohibited by law from grazing, in order to save what is left of the surviving populations and monitor their status and habitat quality, (ii) ex situ, acorns of these oak species (especially Quercus afares and $Q$. xnumidica) previously collected from surroundings than planted in the forest nursery of Aîn Sultan (located within Kroumiria under almost identical conditions and at the same altitude), where a test with more than 900 acorns of zeen oak in recent years showed a success rate of more than $90 \%$ (pers. comm. S. Hamzaoui, forestry technician of Aîn Sultan area). The plant material obtained (about three to five years old plants) will be used later to strengthen existing sporadic wild populations and 
to restore sites where wild populations have been severely damaged, especially in the last decade, following efficient and known guidelines for reintroduction.

\section{Conclusions}

According to the available literature, this is the first record of Quercus xnumidica in the oak forests of Tunisia, and thus its new eastern limit in North Africa. This finding belongs to the plant association Cynosuro peltierii-Quercetum afaredis Laribi ex El Mokni ass. nov. which was also reported for the first time for the Kroumirian Mountains. Both the taxon and the syntaxon contribute to improve and update the knowledge of the chorology and ecology of Tunisian deciduous oaks, the floristic and vegetation richness of Kroumiria, but also underline the urgent need to protect the diversity of ecosystems in these highly disturbed habitats before reaching a stage of no return.

\section{Aknowledgements}

Thanks are due to all colleagues and friends of the Regional Agricultural Development Commission (RADC) of Jendouba and Aîn Draham, forest services of Ghar Dimaou (El Feidja, Aîn Sultan and El Ghorra), Fernana and Aîn Draham (Aîn Draham, Aîn Sellam, Aîn Zana, Tabarka and Babouch) for their technical support and their help during my botanical surveys within Kroumiria region since 2001. I'm deeply grateful to reviewers for their great comments and their excellent improvements to the original version of the manuscript.

Ridha El Mokni (D) https://orcid.org/0000-0003-3849-1039

\section{References}

APD (2021). African Plant Database (version 3.4.0). Retrieved August 15, 2021, from http://www.ville-ge.ch/musinfo/bd/cjb/africa/index. php, Accessed: 10-15.8.2021.

Braun-Blanquet, J. (1964). Pflanzensoziologie: Grundzüge der Vegetationskunde. Springer.

Coombes, A. J., \& Cameron, R. (2021). Quercus ×numidica. Retrieved August 15, 2021, from http://treesandshrubsonline.org/articles/ quercus/quercus-x-numidica/

Coombes, A. J., \& Vázquez, F.M. (2021). Correct citation and lectotypification of Quercus $\times$ kabylica and Q. ×numidica (Fagaceae). Phytotaxa, 478(2), 275-280. https://doi.org/10.11646/phytotaxa.478.2.9

Dobignard, A., \& Chatelain, C. (2010-2013). Index synonymique de la Flore d'Afrique du nord. Vols 1-5. Éditions des Conservatoire et Jardin botaniques de la Ville de Genève.
GBIF [Global Biodiversity Information Facility] (2021). Quercus kabylica Trab. Retrieved August 15, 2021, from https://www.gbif.org/ es/species/2879679.

IUCN [International Union for Conservation of Nature] (2021). The IUCN Red List of Threatened Species. Version 2020-2.

Retrieved August 15, 2021, from https://www.iucnredlist.org.

Laribi, M. (2000). Contribution à l'étude phytosociologique des formations caducifoliées à Quercus canariensis Will. et Q. afares Pom. du massif forestier d'Ath Ghobri-Akfadou (Grande Kabylie). [Unpublished master thesis]. Mouloud Mammeri University of Tizi Ouzou.

Laribi, M., Derridj, A., \& Acherar, M. (2008). Phytosociologie de la forêt caducifoliée à chêne zéen (Quercus canariensis Willd.) dans le massif d'Ath Ghobri-Akfadou (Grande Kabylie, Algérie). Fitosociologia, 45(2), 77-92.

Loisel, R. (1971). Séries de végétation propres, en Provence, aux massifs des Maures et de l'Estérel (ripisylves exclues). Bulletin de la Société botanique de France, 118(3-4), 203-236.

Meddour, R. (1993). Analyse phytosociologique de la chênaie caducifoliée mixte de Tala Kitane (Akfadou, Algérie). Ecologia Mediterranea, 19(3-4), 1-9.

Meddour, R., Meddour-Sahar, O., Derridj, A., \& Géhu, J.M. (2010). Synopsis des groupements végétaux forestiers et préforestiers de la Kabylie djurdjuréenne (Algérie). Revue Forestière Française, 62, 295-308.

Meddour, R., Meddour-Sahar, O. Zeraia, L., \& Mucina, L. (2017). Syntaxonomic synopsis of the forest and tall scrub vegetation of Northern Algeria. Lazaroa, 38(2), 127-163. https://doi.org/10.5209/ LAZA. 53272

Mucina, L., Bültmann, H., Dierßen, K., Theurillat, J.-P., Raus, T., Čarni, A., Šumberová, K., Willner, W., Dengler, J., Gavilán García, R., Chytrý, M., Hájek, M., Di Pietro, R., Iakushenko, D., Pallas, J., Daniëls, F. J. A., Bergmeier, E., Santos Guerra, A., Ermakov, N., Valachovič, M., Schaminée, J. H. J., Lysenko, T., Didukh, Y. P., Pignatti, S., Rodwell, J. S., Capelo, J., Weber, H. E., Solomeshch, A., Dimopoulos, P., Aguiar, C., Hennekens, S. M., \& Tichý, L. (2016). Vegetation of Europe: Hierarchical floristic classification system of vascular plant, bryophyte, lichen, and algal communities. Applied Vegetation Science, 19(Suppl. 1), 3-264. https://doi.org/10.1111/avsc.12257

Quézel, P., \& Santa, S. (1962). Nouvelle flore de l'Algérie et des régions désertiques méridionales. Édit. CNRS.

Theurillat, J. P., Willner, W., Fernández-González, F., Bültmann, H., Čarni, A., Gigante, D., Mucina, L., \& Weber, H. (2020). International Code of Phytosociological Nomenclature. 4th edition. Applied Vegetation Science, 24, Article e12491. https://doi.org/10.1111/avsc.12491

Thiers, B. (2021). Index Herbariorum: A global directory of public herbaria and associated staff. Retrieved August 15, 2021, from http:// sweetgum.nybg.org/ih.

Trabut, L. C. (1889). Les hybrides du Quercus suber. Association Française pour l'Avancement des Sciences, 18(1), 300.

Trabut, L. C. (1890). Les hybrides du Quercus suber, principalement en Algérie. Association Française pour l'Avancement des Sciences, 18(2), 503-507. 
Table 1: Floristic relevés for Quercus ×numidica Trabut plant community (2018-2020) within Tunisian oak forests (Jendouba/ Aîn Draham/Aîn zana, NW of Tunisia), (-, no report; +, present with more than 10 spontaneous individuals within the reported population of Quercus afares Pomel; 1, 2, 3 and 4 are following the Braun-Blanquet cover-abundance scale; *indicates endemic taxa to Tunisia and its very close neighboring countries; indicates pastoral plants).

Tabela 1: Popisi združbe z Quercus ×numidica Trabut, narejeni v zadnjih nekaj letih (2018-2020) v hrastovih gozdovih v Tuniziji (Jendouba/Aîn Draham/Aîn zana, SZ Tunizije), (-, ni prisotna; +, prisotnih več kot 10 spontano rastočih osebkov populaciji vrste Quercus afares Pomel; 1, 2, 3 in 4 ustrezajo lestvici pokrovnosti in številčnosti po Braun-Blanquetu; *označuje endemične taksone v Tuniziji in sosednjih državah; označuje rastline, značilne za pašne površine).

\begin{tabular}{lcc}
\hline Relevé number & 1 & 2 (Holotypus) \\
Biogeographical entity & Kroumiria & Kroumiria \\
Site & Oak forests of Kroumiria & $\begin{array}{c}\text { Oak forests of Kroumiria } \\
\text { (Jendouba/Aîn Draham/Aîn Zana) }\end{array}$ \\
Date & 12.07 .2018 & 16.06 .2020 \\
Vegetation coverage (\%) & $85-90$ & $90-95$ \\
Surface area $\left(\mathrm{m}^{2}\right)$ & 256 & 256 \\
Altitude $(\mathrm{m}$ a.s.l.) & $886.6-954.8$ & $886.6-954.8$ \\
Coordinates & $036^{\circ} 44^{\prime} 12^{\prime \prime} \mathrm{N} 008^{\circ} 51^{\prime} 34^{\prime \prime} \mathrm{E}$ & $036^{\circ} 44^{\prime} 12^{\prime \prime} \mathrm{N} 008^{\circ} 51^{\prime} 34^{\prime \prime} \mathrm{E}$ \\
\hline
\end{tabular}

Diagnostic species of the Cynosuro peltierii-Quercetum afaredis association

* Quercus afares Pomel

\section{3}

* Cynosurus peltieri Maire

* Galium tunetanum Lam.

* Quercus ×numidica Trab.

* Phlomis bovei de Noé subsp. bovei

Diagnostic species of the Quercion suberis alliance

Quercus suber L.

* Teucrium atratum Pomel

Cytisus villosus Pourr.

Melica minuta L.

Pulicaria odora (L.) Rchb.

Genista ulicina Spach

Diagnostic species of the Quercetalia ilicis order

* Quercus canariensis Willd.

Erica arborea L.

Galium rotundifolium L.

Geranium purpureum Vill.

* Cyclamen africanum Boiss. \& Reut.

Luzula forsteri (Sm.) DC.

Phillyrea latifolia L.

Asplenium adiantum-nigrum $\mathrm{L}$.

Cytisus villosus Pourr.

Diagnostic species of the Quercetea ilicis class

Arbutus unedo L.

Erica arborea L.

Geranium purpureum Vill.

* Plagius maghrebinus Vogt \& Greuter

Daphne gnidium L. subsp. gnidium

Selaginella denticulata (L.) Spring

Smilax aspera L.

* Eryngium tricuspidatum subsp. bovei (Boiss.) Breton
1

$+$

2

1

1

1

1

1

3

2

$$
1
$$$$
1
$$$$
1
$$$$
1
$$$$
2
$$$$
1
$$$$
1
$$

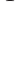

2

\section{2}

\section{1}

\section{1}

1

1

1 


\section{Companion species}

Aira tenorei Guss.

- Andryala integrifolia L.

- Asphodelus ramosus L.

Asplenium trichomanes $\mathrm{L}$.

Briza maxima $\mathrm{L}$.

Bromus hordeaceus L. subsp. hordeaceus

Campanula rapunculus L.

Catapodium rigidum (L.) C.E. Hubb.

Clinopodium vulgare $\mathrm{L}$.

Cynosurus echinatus L.

Dactylis glomerata L. subsp. glomerata

Diatelia tuberaria (L.) Demoly

Elaeoselinum asclepium subsp. meoides (Desf.) Fiori

Ficaria verna Huds.

Filago asterisciflora (Lam.) Sweet

Filago pyramidata L.

Fumana juniperina (Lag. ex Dunal) Pau

* Galactites mutabilis Durieu

Gaudinia fragilis (L.) P. Beauv.

Geranium atlanticum Boiss.

Geranium lucidum L.

Geranium robertianum L.

Holcus lanatus L.

Hordeum bulbosum L.

* Hyacinthoides aristidis (Coss.) Rothm.

Klasea flavescens subsp. mucronata (Desf.) Cantó \& Rivas Mart.

Lagurus ovatus L. subsp. ovatus

1

1

Legousia falcata (Ten.) Janch.

Lens sp.

Lens nigricans (M. Bieb.) Godr.

* Ophrys tenthredinifera subsp. ficalhoana (J.A. Guim.)

M.R. Lowe \& D. Tyteca

* Plantago lagopus L.

* Platanthera bifolia subsp. kuenkelei (H. Baumann)

Kreutz

Polypodium cambricum L.

Rubus ulmifolius Schott

Rumex tuberosus L.

Sedum cepaea L.

Sherardia arvensis $\mathrm{L}$.

Stachys arvensis $\mathrm{L}$.

* Trifolium campestre Schreb.

* Trifolium cherleri L.

Trifolium pratense $\mathrm{L}$.

- Trifolium stellatum L.

Vicia bithynica (L.) L. 